ISSN: p. 2354-354X e. 2354-3515

Open Access Journal, Available Online

\title{
Cyberbullying, Demography and Coping Strategies among Nigerian Students
}

\author{
Razak Owolabi (Ph.D.) \\ News Agency of Nigeria (NAN), Lagos, Nigeria \\ razakowolabi@gmail.com
}

Received: 10 Dec. 2019 Accepted: 22 May 2020 Date of Publication: June 2020

Abstract: Cyberbullying is a concern among the youth in many parts of the world. The highly visible literature on the subject demonstrates the disquiet. This work investigates the Nigerian dimension by examining the demographic implications of online coping strategies of 1,000 students from six Nigerian universities. Findings show that demography significantly influences the adoption of coping strategies against cyberbullying $\left(F_{(1,814)}=45.232, A d j . R^{2}=0.246, p<0.05\right)$. One of the recommendations made is that anti-cyberbullying messages and preventive campaigns from university authorities should focus on single students and students who are new on the campus as they are more vulnerable to attacks than older and married colleagues. The study underscores this measure as a way of putting in check the menace of cyberbullying and its devastating effects on the mental and physical development of young people.

Keywords: Cyberbullying, demography, coping strategies, students, youth. 


\section{Introduction}

Researchers working on social media engagements (Crick \& Grotpeter, 1996; Bjorkqvist, Lagerspetz \& Kaukiainen, 1992; Wolke, Woods \& Bloomfield, 2000, Okorie, Loto \& Omojola, 2018) have identified two forms of bullying. First is direct bullying, which includes physical and verbal acts of aggression, and second, indirect bullying, which is characterized by social exclusion and rumor-mongering. The advent of the internet has led to the emergence of a new type called cyberbullying. The youth or children who are bullied physically can also be bullied online. Cyberbullying shares similar attributes with the traditional variety, but its online dimension means that perpetrators do sometimes hide their true identities. Cyberbullying can be perpetrated by sharing harsh or intimidating texts, fake profiles, e-mails, embarrassing or scandalous personal pictures or videos of a person, and rumors, through social media. Online ill-treatment and domination can happen in a few minutes and go for hours, days, weeks, months, or years!

Extant literature shows that generally, very little has been done in Nigeria on cyberbullying research and documentation, much less examining the influence of demographic features on how students cope with online attacks from bullies. This is a gap this paper seeks to fill by looking at students in selected Nigerian universities and how their demographic composition influences their responses to incidents of cyberbullying.

The risks associated with cyberbullying victims include fear, distress, psychosomatic problems such as recurring abdominal pain, headaches, and sleeping problems. Other risks are: the student feeling uncared for by teachers, emotional and peer problems, high level of perceived difficulties, somatic illness, high level of conduct problems, regular smoking, hyperactivity, drunkenness, and substance abuse (Sourander, Klomek, Ikonen, Lindroos, Luntamo, Koskelainen, Ristkari, \& Helenius, 2010). According to Hinduja and Patchin (2010), cyber victimization has a linkage with suicide in some extreme cases. From these risk factors, cyberbullying is viewed as a severe social, psychological, and health problems by many researchers.

\section{Objectives of the study}

Objectives of the study are the following:

1. to examine the role of demography in the adoption of coping strategies against cyberbullying by students in the selected higher educational institutions, 
2. to identify coping strategies adopted against cyberbullying communication by students in the selected higher educational institutions.

\section{Research Question}

1. What types of coping strategies are being adopted against cyberbullying communication by students in the selected higher educational institutions?

\section{Hypothesis}

1. Students' demography does not significantly influence their adoption of coping strategies against cyberbullying communication

\section{Significance of the study}

Generally, the study of demography, cyberbullying, and coping strategies among students of higher educational institutions in Nigeria would add to knowledge as not much has been done in this area of research. The study could be of considerable significance to university administrators as some of the strategies used in fighting cyberbullying, identified in the study could be adopted to curb the menace in the country's universities. The administrators will always want undergraduates to excel in academic performance, as such feat will add to the glory of their universities. Lecturers will not enjoy the company undergraduates who may not concentrate during lectures or who cannot attend classes regularly all due to their exposure to cyberbullying and its concomitant debilitating communication.

\section{Literature Review}

\section{a. The concept of Demography and Cyberbullying}

One of the aggressive expressions noticeable in human interactions is physical bullying. Cyberbullying is the sharing or sending of insults, abuses, taunts, and other similar forms of messages through video, texts, and audio from a perpetrator who is the bully to a victim, usually by the internet and other electronic means. Demography is the study of the human population and how the population changes. Among the variables in demography are age, sex, race, level of income, level of education, and employment. The age group commonly involved in the cyberbullying attacks, whether as perpetrators, victims, or eyewitnesses, is the youth (Folayan et al., 2018; Omojola, 2009. The youth, especially undergraduates, are the most active population segment on the internet and are fond of cyberbullying. Studies have shown that they are heavy and most regular users of the internet when compared with the general population of people in society (Amodu et al., 2019; Omojola, 
2008; 2010; Jones, 2002; Kumar \& Kaur, 2006,). Online forums such as social media are fertile destinations for young people to assault one another at any time of the day or night (Subrahmanyam \& Greenfield, 2008).

The Cyberbullying Research Centre has been at the forefront, investigating cyberbullying among adolescents. The two directors of the center, Dr. Sameer Hinduja of Florida Atlantic University and Dr. Justin Patchin of the University of Wisconsin-Eau Claire, have done much work on cyberbullying. The researchers have been studying the phenomenon since 2002 and launched their website for this purpose, cyberbullying.org, in 2005. They are authors of many publications and journal articles which are useful.

\section{b. Emotions, demography, and cyberbullying}

Concerning demography and cyberbullying, research by the Cyberbullying Research Centre has shown that females are more sensitive than males in responding to cyberbullying due to the emotional set up typical of the female gender. The 468 female students investigated in one of their studies were reported frustrated (39.6\%), angry (36\%), and sad $(25.2 \%)$ more often than their male counterparts who had lower percentages, 27.5 percent, 24.3 percent, and 17.9 percent respectively. The study concluded that the result was not unusual as males are reluctant to admit weaknesses when it involves emotions. Males are expected to be rated higher in showing emotions having to do with anger and frustration. (Hinduja \& Patchin, 2009, Moran \& Omojola, 2014).

The emotional repercussions of cyberbullying across age groups were the subject of another study conducted by the Centre. The result showed that anger and frustration remained the dominant responses among senior and junior high school students. However, students at the elementary level were more likely to feel sad as a result of being bullied online (Hinduja \& Patchin, 2009). The Centre reported that the outcome of the study was so because, at a younger age, children were not battling with the same kind of competitive social hierarchy typically found within schools at a higher level. So, rather than feeling the need to prove themselves among their peers, students at the elementary level tend to keep bottled up within them, the initial emotional responses to bullying.

This is a pointer to the notion that younger children may keep their initial emotional responses to themselves rather than displaying outward actions. Sadly, enough, 
over time, the emotions are likely to develop to a level with serious health implications if not well managed. An increase in emotional distress related explicitly to cyberbullying was also reported in a 2003 extensive survey, which focused on the clinical effects of cyberbullying. In the study which brought together 512 professionals from psychology, psychiatry, and social work backgrounds, it was reported that for "one-third $(34 \%)$ of the youth sampled; the internet problem played a primary role in the client's treatment" (Mitchell, Finelhot \& Becker-Blease, 2007, p. 48). This outcome shows that cyberbullying is having noticeable clinical effects on the youth.

\section{c. Gender and Cyberbullying}

According to some studies (Boulton \& Underwood, 1992; Olweus, 1991; Seals \& Young, 2003; Borg, 1999, Omojola, 2014), gender plays a crucial role in traditional forms of bullying. For instance, males are more likely to be bullied than females (Kumpulainen, Rasanen, \& Henttonen, 1999; Eslea \& Mukhtar, 2000). Males also reported themselves bullying others at significantly higher rates than their female counterparts (Kumpulainen, Rasanen, Henttonen, \& Almqvist, 1998; Hoover \& Olsen, 2001). Furthermore, males with atypical or unusual gender-related behaviors are at a much higher risk for peer assault than other young males. Moreover, for females, those perceived to be less or more attractive than others are at the highest risk for harassment (Shakeshaft et al., 1995). In another study by Crick et al. (1999), gender differences concerning bullying were discovered in preschoolers as young as 3 to 5 years old. The study shows that, to a small extent, males are significantly more physically victimized than females, while females are more relationally victimized. In a similar vein, Wiseman (2002) found that concerning bullying other people, males used their fists and physical threats more. However, weapons used by females were words and behind-the-scenes school bully manipulation. The cases listed are on traditional bullying; as such, there is a need to also look at gender relations concerning cyberbullying.

In a study of cyberbullying as it relates to gender differences $(\mathrm{Li}$, 2006), the researcher examined the level to which students from three junior high schools in Canada experienced cyberbullying. Also, the researcher looked at the experience of respondents on traditional bullying for a better understanding of cyberbullying. The result showed that close to half of the respondents were victims, 
while about one in four respondents had been bullied online in the past. It was discovered that over 34 percent of the respondents had bullied others in the traditional form, and almost 17 percent had bullied others using electronic communication tools. Also, 53.6 percent of the respondents sampled reported that they knew someone being bullied online. The researcher also looked at male and female respondents' experiences separately and discovered that over 22 percent of males and close to 12 percent of females were cyberbullied. However, 25 percent of males and 25.6 percent of females reported that they had been bullied online. Reporting incidents of cyberbullying to trusted persons or people in authority is a primary coping strategy identified by researchers. For the Li study, the question of when cyberbullying occurs, who will tell adults among male or female respondents, was examined. Moreover, the result showed that for cyber victims, females were more likely to inform adults than males.

\section{d. Coping strategies and cyberbullying}

In another study, Cassidy, Jackson, and Brown (2009) asked some students in Canada to mention whom they would tell when they experienced cyber victimization. From the responses, 47 percent mentioned school staff, 74 percent of the respondents reported that they would tell a friend, while 57 percent mentioned a parent or guardian. The researchers discovered that within the sampled respondents, their readiness to tell either school staff or a parent decreased with their age. Although these numbers looked reasonably encouraging, they, however, went down drastically when the victims of cyberbully were asked about what they did.

In a study of Dutch adolescents, Dehue, Bollman, and Vollink (2008) also asked victims what they did to cope with online attacks. Results showed that 13 percent told a friend, nine percent told their parents, seven percent did not tell anyone while just two percent told a teacher. In the case of Smith et al. (2008), the researchers discovered that 16 percent of victimized respondents in their study sought help from parents and nine percent from teachers. However, in the work of Livingstone, Haddon, Görzig, and Ólafsson (2011), the researchers found that 77 percent of the cyber victims had talked to someone about their experience: 52 percent told a friend, 13 percent told a sibling, 42 percent talked to a parent, eight percent told another adult they trusted, and seven percent told a teacher. The samples were children aged nine to 16 years 
in 25 different countries According to Slonje et al., (2013), reporting a cyberbullying incident seems to be the last course of action the respondents took, that is if they took any action at all following such incidents.

Slonje and Smith (2008) discovered that students viewed adults as people who were unaware of the problem at hand. This could be interpreted to mean that they think adults will not be able to handle the problem well if they tell them. In short, students often talked about technical coping strategies such as blocking people online, changing one's password, username, or mobile phone number, when they were asked about steps they adopted in coping with victimization. However, most studies found that only a few of the students sampled sought help from other people. However, a consistent finding was that if at all these students decided to tell somebody, their first choice was usually a friend, followed by a parent and lastly one of their teachers.

On the reporting of incidents of cyberbullying by victims, a study showed that up to 80 percent of regular bullying incidences were not reported to the staff of educational institutions or schools (Rigby \& Slee, 1999). A study by Li (2007) showed that the vast majority of the students who were bullied online or who knew someone being bullied online preferred to stay quiet rather than inform adults. The possible explanation in this regard might be that many students, over one-third of the students in the study sample, did not think that adults in schools would make an effort to stop cyberbullying brought to their notice. Owing to this belief that adults in schools were helpless, many students, feeling either scared or powerless, would not report cyberbullying cases. This substantiates the literature that adolescents' perceptions of their school environments relate to their bullying-related behaviors (Pellegrini \& Bartini, 2000). It brings to the fore the importance of building, and further strengthening, a good relationship between students and school staff, made up of teachers, administrators, and others.

Another explanation may be students' lack of appropriate strategies to deal with the problems. As the data indicate, most victims and bystanders do not report cyberbullying incidents. Female cyber victims, however, are more inclined to inform adults about the incidents than male cyber victims, according to the findings. This is an exciting discovery, and it likely has to do with the gender 
differences identified in conversational styles (Tannen, 1994). In her work, Tannen indicated that "men are more likely to be aware that asking ... for any kind of help, puts them in a onedown position" (p. 24). As a result, males tend not to ask for help or inform others about their troubles.

Many cyberbullying researchers direct their focus on young people aged 11 years and above. Estimates of prevalence among adolescents vary depending on methodology. However, in the UK, Smith et al. (2008a) reported that 6.6 percent of adolescents sampled in their study reported being bullied online 'often' and 15.6 percent 'once or twice.' Children under the age of 11 years also used the internet and mobile phones (Byron Review, 2008; Carphone Warehouse, 2006). Monks et al. (2009) asserted in their findings that 72 percent of seven to 11 years of age owned a mobile phone, and 87 percent had internet access at home. In the UK, two small-scale studies showed that children in primary schools reported that they were being bullied online. The Anti-Bullying Alliance (ABA, 2009) discovered that about 20 percent of children from 10 to 11 years of age were bullied online. Similar levels were discovered among seven- to 11year-olds, five percent aggressors, and 23 percent victims (Monks et al., 2009).

\section{e. Theoretical framework}

The present paper is rooted in the Social Influence Theory propounded by Herbert C. Kelman (1958). The theory relates to an individual's attitudes, beliefs, and resulting behavior being greatly influenced by others through the three processes of compliance, identification, and internalization. Concerning compliance, this is when individuals embrace influence and the subsequent behavior in order to get approval or disapproval, reward or punishment as the case may be. Identification occurs when people adopt a behavior to maintain a good relationship with other people or groups. Internalization is assumed when individuals examine the content of induced behavior, and this makes them accept influence. The theory's relevance to the paper could be seen in the situation that respondents'

characteristics demographic influenced their adopted coping strategies. Respondents' marital status, year of study, and level of studentship are demographic variables found in the study to have some level of influence on their exposure and response to cyberbullying. 


\section{Methodology}

The study adopted survey research with a quantitative approach as its research design. Copies of questionnaires were distributed to undergraduates in six selected universities. A survey as a research method is "the collection of information from a sample of individuals through their responses to questions" (Check \& Schutt, 2012, p. 160) to describe the behavior of the entire population towards the phenomenon under investigation. The survey research method provides an opportunity for the researcher to select participants from the population of interest, collect data from them utilizing any of the various methods of instrumentation (Ponto, 2015), and generalize on the whole population based on the responses of the sample. The quantitative approach, among other benefits, involves gathering numerical data, figures, and statistics, which enables for exactness of data. Figures are easily attached to issues when analyzing data. However, the approach neglects the dynamic nature of human beings and the hidden motives behind a particular behavior.

Concerning the study population, Ojebode, Onekutu and
Adegbola (2010) affirm that the population of any study is the aggregate of people or objects that the researcher is studying. Members of a population must share at least one characteristic that differentiates them from nonmembers. The population of the study $(81,415)$ consists of all undergraduates in the four public and two private universities of the two Nigerian states, Lagos and Kwara, selected for the present study. The universities are Lagos State University, Ojoo; University of Lagos, Akoka; University of Ilorin, Kwara State; Kwara State University, Malete; Pan Atlantic University, Lagos; and Al-Hikmah University, Kwara. The sampling formula of Saunders, Lewis and Thornhill (2009) was used to determine the sample size of the study. It involved three stages that ultimately led to the actual sample size. The confidence level was 95 percent, thus making available five percent error margin. The sample size was 765 . This figure was increased to 1,000 to align with the accepted sample size for this type of multivariate study, according to Comrey and Lee (1992), cited by Wimmer and Dominick (2011). The response rate of the instrument was 82 percent. 


\section{Analysis and Findings}

\section{Analysis of Demographic characteristics}

Table 1: Demographic Characteristics of Respondents

\begin{tabular}{|c|c|c|c|}
\hline \multicolumn{2}{|l|}{ Variable } & $\mathrm{f}$ & $\%$ \\
\hline \multirow[t]{5}{*}{ Age } & $16-20$ & 155 & 19.0 \\
\hline & $21-35$ & 638 & 78.2 \\
\hline & $26-30$ & 19 & 2.3 \\
\hline & $31-35$ & 4 & .5 \\
\hline & Total & 816 & 100.0 \\
\hline \multirow[t]{3}{*}{ Gender } & Male & 342 & 41.9 \\
\hline & Female & 474 & 58.1 \\
\hline & Total & 816 & 100.0 \\
\hline \multirow[t]{6}{*}{ Year of study } & 100 & 52 & 6.4 \\
\hline & 200 & 268 & 32.8 \\
\hline & 300 & 215 & 26.3 \\
\hline & 400 & 275 & 33.7 \\
\hline & 500 & 6 & .7 \\
\hline & Total & 816 & 100.0 \\
\hline \multirow[t]{3}{*}{ Religion } & Christianity & 342 & 41.9 \\
\hline & Islam & 474 & 58.1 \\
\hline & Total & 816 & 100.0 \\
\hline \multirow[t]{3}{*}{ Marital status } & Single & 648 & 79.4 \\
\hline & Married & 168 & 20.6 \\
\hline & Total & 816 & 100.0 \\
\hline \multirow[t]{7}{*}{ Institution } & UNILAG & 222 & 27.2 \\
\hline & LASU & 73 & 8.9 \\
\hline & UNILORIN & 299 & 36.6 \\
\hline & KWASU & 175 & 21.4 \\
\hline & AL-HIKMAH & 38 & 4.7 \\
\hline & PAN ATLANTIC & 9 & 1.1 \\
\hline & Total & 816 & 100.0 \\
\hline
\end{tabular}

From Table 1, the majority of the participants were young because they were between the ages of 16 to 25 (97.2\%). Female respondents
$(58.1 \%)$ were more than their male (41.9\%) counterparts. Also, participants from 200 level and 400 level had 32.8 and 33.7 percent

URL: http://journals.covenantuniversity.edu.ng/index.php/cjoc 
representation, while those in 300 level had 26.3 percent proportion of representation in the study. However, those with an advanced level of studentship had the lowest representation in the study (500 level, $0.7 \%$ ). Participants who were Muslims were the majority (58.1\%), Christians, on the other hand, were 41.9 percent of the study participants. Single respondents were the majority (79.4\%), while those who were married constituted 20.6 percent. Finally, participants from
UNILORIN $(36.6 \%)$ were more than those from UNILAG (27.2\%), KWASU (21.4\%), LASU (8.9\%) and Al-Hikmah University $(4.7 \%)$; while respondents from Pan Atlantic University were the least represented $(1.1 \%)$.

1. Research Question: What types of coping strategies are being adopted against cyberbullying communication by students in the selected higher educational institutions?

2. Table 2a: Cyberbullying Coping Strategies Adopted by Participants (Technical Strategies)

\begin{tabular}{|c|c|c|c|c|c|c|c|c|}
\hline \multirow[t]{3}{*}{ Items } & SA & $\mathbf{A}$ & D & SD & $\mathbf{U}$ & $\bar{x}$ & SD & $\mathbf{A M}$ \\
\hline & $\mathrm{F}$ & $\mathrm{F}$ & $\mathrm{F}$ & $\mathrm{F}$ & $\mathrm{F}$ & & & \\
\hline & $(\%)$ & $(\%)$ & $(\%)$ & $(\%)$ & $(\%)$ & & & \\
\hline \multicolumn{9}{|l|}{ Technical strategies } \\
\hline $\begin{array}{l}\text { I set my profile to private, so } \\
\text { only my known friends will have } \\
\text { access to me on the Internet }\end{array}$ & $\begin{array}{l}548 \\
(67.2)\end{array}$ & $\begin{array}{l}51 \\
(6.3)\end{array}$ & $\begin{array}{l}207 \\
(25.4)\end{array}$ & $\begin{array}{l}6 \\
(0.7)\end{array}$ & $\begin{array}{l}4 \\
(0.5)\end{array}$ & 4.39 & 0.92 & \multirow{5}{*}{$\begin{array}{l}\text { Average } \\
\text { Mean } \\
\mathbf{3 . 8 9}\end{array}$} \\
\hline $\begin{array}{l}\text { I blacklist cyberbullies' number } \\
\text { on my phone contact list }\end{array}$ & $\begin{array}{l}511 \\
(62.6)\end{array}$ & $\begin{array}{l}23 \\
(2.8)\end{array}$ & $\begin{array}{l}152 \\
(18.6)\end{array}$ & $\begin{array}{l}57 \\
(7)\end{array}$ & $\begin{array}{l}73 \\
(8.9)\end{array}$ & 4.03 & 1.38 & \\
\hline $\begin{array}{l}\text { I block cyberbullies' text } \\
\text { messages from my phone inbox }\end{array}$ & $\begin{array}{l}504 \\
(61.8)\end{array}$ & $\begin{array}{l}25 \\
(3.1)\end{array}$ & $\begin{array}{l}157 \\
(19.2)\end{array}$ & $\begin{array}{l}57 \\
(7)\end{array}$ & $\begin{array}{l}73 \\
(8.9)\end{array}$ & 4.02 & 1.38 & \\
\hline $\begin{array}{l}\text { I track the Internet address of } \\
\text { cyberbully and expose him to } \\
\text { other people on the internet. }\end{array}$ & $\begin{array}{l}150 \\
(18.4)\end{array}$ & $\begin{array}{l}262 \\
(32.1)\end{array}$ & $\begin{array}{l}235 \\
(39.8)\end{array}$ & $\begin{array}{l}10 \\
(1.2)\end{array}$ & $\begin{array}{l}69 \\
(8.5)\end{array}$ & 3.51 & 1.07 & \\
\hline $\begin{array}{l}\text { I bully (attack) the cyberbully } \\
\text { back directly after hacking his } \\
\text { Internet account. }\end{array}$ & $\begin{array}{l}169 \\
(20.7)\end{array}$ & $\begin{array}{r}242 \\
(29.7)\end{array}$ & $\begin{array}{r}231 \\
(28.3)\end{array}$ & $\begin{array}{r}174 \\
(21.3)\end{array}$ & - & 3.50 & 1.05 & \\
\hline
\end{tabular}

KEY: $\mathrm{SA}=$ Strongly Agree, $\mathrm{A}=$ Agree, $\mathrm{D}=$ Disagree, $\mathrm{SD}=$ Strongly Disagree, $* * *$ Decision Rule if mean is $\leq 1.49$ Undecided; 1.5 to $2.49=$ Strongly Disagree; 2.5 to $3.49=$ Disagree; 3.5 to $4.49=$ Agree; 4.5 to $5=$ Strongly Agree 
Table 2b: Cyberbullying Coping Strategies Adopted by Participants (Preventive Strategies)

\begin{tabular}{|c|c|c|c|c|c|c|c|c|}
\hline \multirow[t]{3}{*}{ Items } & $\mathbf{S A}$ & $\mathbf{A}$ & $\mathbf{D}$ & SD & $\mathbf{U}$ & $\bar{x}$ & SD & $\overline{\mathbf{A M}}$ \\
\hline & $\mathrm{F}$ & $\mathrm{F}$ & $\mathrm{F}$ & $\mathrm{F}$ & $\mathrm{F}$ & & & \\
\hline & $(\%)$ & $(\%)$ & $(\%)$ & $(\%)$ & $(\%)$ & & & \\
\hline \multicolumn{9}{|l|}{ Preventive Strategies } \\
\hline $\begin{array}{l}\text { I protect my password } \\
\text { on Internet sites }\end{array}$ & $\begin{array}{c}633 \\
(77.6) \\
\end{array}$ & $\begin{array}{c}87 \\
(10.7) \\
\end{array}$ & $\begin{array}{c}6 \\
(0.7) \\
\end{array}$ & - & $\begin{array}{c}90 \\
(11) \\
\end{array}$ & 4.44 & 1.26 & \multirow{6}{*}{$\begin{array}{l}\begin{array}{l}\text { Avera } \\
\text { ge }\end{array} \\
\text { Mean } \\
3.66 \\
\end{array}$} \\
\hline $\begin{array}{l}\text { I stay away from } \\
\text { unsafe websites }\end{array}$ & $\begin{array}{c}632 \\
(77.5) \\
\end{array}$ & $\begin{array}{c}86 \\
(10.5) \\
\end{array}$ & $\begin{array}{c}4 \\
(0.5) \\
\end{array}$ & $\begin{array}{c}4 \\
(0.5)\end{array}$ & $\begin{array}{c}90 \\
(11)\end{array}$ & 4.43 & 1.27 & \\
\hline $\begin{array}{l}\text { I avoid posting my } \\
\text { personal information } \\
\text { on Internet }\end{array}$ & $\begin{array}{c}409 \\
(50.1)\end{array}$ & $\begin{array}{c}198 \\
(24.3)\end{array}$ & $\begin{array}{c}11 \\
(1.3)\end{array}$ & $\begin{array}{c}100 \\
(12.3)\end{array}$ & $\begin{array}{c}98 \\
(12)\end{array}$ & 3.88 & 1.44 & \\
\hline $\begin{array}{l}\text { I change my phone } \\
\text { password regularly }\end{array}$ & $\begin{array}{c}141 \\
(17.3) \\
\end{array}$ & $\begin{array}{r}206 \\
(25.2) \\
\end{array}$ & $\begin{array}{l}253 \\
(31) \\
\end{array}$ & $\begin{array}{c}126 \\
(15.4)\end{array}$ & $\begin{array}{c}90 \\
(11)\end{array}$ & 3.22 & 1.22 & \\
\hline $\begin{array}{l}\text { I avoid putting my real } \\
\text { pictures on the } \\
\text { Internet }\end{array}$ & $\begin{array}{c}203 \\
(24.9)\end{array}$ & $\begin{array}{r}113 \\
(13.8)\end{array}$ & $\begin{array}{c}183 \\
(22.4)\end{array}$ & $\begin{array}{c}218 \\
(26.7)\end{array}$ & $\begin{array}{c}99 \\
(12.1)\end{array}$ & 3.13 & 1.37 & \\
\hline $\begin{array}{l}\text { I talk to known bully } \\
\text { to settle any } \\
\text { disagreement in time }\end{array}$ & $\begin{array}{c}109 \\
(13.4)\end{array}$ & $\begin{array}{r}179 \\
(21.9)\end{array}$ & $\begin{array}{c}131 \\
(16.1)\end{array}$ & $\begin{array}{r}307 \\
(37.6)\end{array}$ & $\begin{array}{c}90 \\
(11)\end{array}$ & 2.89 & 1.25 & \\
\hline
\end{tabular}

KEY: SA=Strongly Agree, A=Agree, $\mathrm{D}=$ Disagree, $\mathrm{SD}=$ Strongly Disagree, ***Decision Rule if mean is $\leq$ 1.49 Undecided; 1.5 to $2.49=$ Strongly Disagree; 2.5 to $3.49=$ Disagree; 3.5 to $4.49=$ Agree; 4.5 to $5=$ Strongly Agree.

Table 2c: Cyberbullying Coping Strategies Adopted by Participants (Reactive Strategies)

\begin{tabular}{|c|c|c|c|c|c|c|c|c|}
\hline \multirow[t]{3}{*}{ Items } & SA & $\mathbf{A}$ & D & SD & $\mathbf{U}$ & $\bar{x}$ & SD & $\mathbf{A M}$ \\
\hline & $\mathrm{F}$ & $\mathrm{F}$ & $\mathrm{F}$ & $\mathrm{F}$ & $\mathrm{F}$ & & & \\
\hline & $(\%)$ & $(\%)$ & (\%) & $(\%)$ & $(\%)$ & & & \\
\hline \multicolumn{8}{|l|}{ Reactive Strategies } & \\
\hline $\begin{array}{l}\text { I delete bully's } \\
\text { messages on my } \\
\text { phone or computer }\end{array}$ & $\begin{array}{c}482 \\
(59.1)\end{array}$ & $\begin{array}{c}88 \\
(10.8)\end{array}$ & $\begin{array}{c}131 \\
(16.1)\end{array}$ & $\begin{array}{c}10 \\
(1.2)\end{array}$ & $\begin{array}{r}105 \\
(12.9)\end{array}$ & 4.02 & 1.40 & \\
\hline $\begin{array}{l}\text { I close my account on } \\
\text { the website/social } \\
\text { media where I was } \\
\text { bullied online }\end{array}$ & $\begin{array}{c}366 \\
(44.9)\end{array}$ & $\begin{array}{c}82 \\
(10)\end{array}$ & $\begin{array}{c}226 \\
(27.7)\end{array}$ & $\begin{array}{c}21 \\
(2.6)\end{array}$ & $\begin{array}{c}121 \\
(14.8)\end{array}$ & 3.68 & 1.44 & \\
\hline $\begin{array}{l}\text { I accept cyberbullying } \\
\text { as normal situation }\end{array}$ & $\begin{array}{c}158 \\
(19.4)\end{array}$ & $\begin{array}{r}244 \\
(29.9) \\
\end{array}$ & $\begin{array}{c}184 \\
(22.5) \\
\end{array}$ & $\begin{array}{c}161 \\
(19.7)\end{array}$ & $\begin{array}{c}69 \\
(8.5) \\
\end{array}$ & 3.32 & 1.23 & \multirow{3}{*}{$\begin{array}{c}\text { Average } \\
\text { mean } \\
\mathbf{3 . 3 6}\end{array}$} \\
\hline $\begin{array}{l}\text { I report cyberbullying } \\
\text { to police or relevant } \\
\text { authorities }\end{array}$ & $\begin{array}{c}105 \\
(12.9)\end{array}$ & $\begin{array}{r}157 \\
(19.2)\end{array}$ & $\begin{array}{c}241 \\
(29.5)\end{array}$ & $\begin{array}{r}202 \\
(24.8)\end{array}$ & $\begin{array}{r}111 \\
(13.6)\end{array}$ & 2.93 & 1.22 & \\
\hline $\begin{array}{l}\text { I report cyberbullying } \\
\text { to my parents or } \\
\text { guardians }\end{array}$ & $\begin{array}{l}114 \\
(14)\end{array}$ & $\begin{array}{c}101 \\
(12.4)\end{array}$ & $\begin{array}{l}280 \\
(34.3)\end{array}$ & $\begin{array}{c}213 \\
(26.1)\end{array}$ & $\begin{array}{r}108 \\
(13.2)\end{array}$ & 2.88 & 1.21 & \\
\hline
\end{tabular}

The average mean for all coping strategies is 3.64

KEY: SA=Strongly Agree, A=Agree, D=Disagree, $\mathrm{SD}=$ Strongly Disagree, ***Decision Rule if mean is $\leq 1.49$ Undecided; 1.5 to $2.49=$ Strongly Disagree; 2.5 to 3.49 =Disagree; 3.5 to $4.49=$ Agree; 4.5 to $5=$ Strongly Agree 
Tables $2 \mathrm{a}, 2 \mathrm{~b}$, and $2 \mathrm{c}$ show that generally, respondents agreed that they adopted cyberbullying coping strategies $(\overline{\mathrm{x}}=3.64)$. Respondents adopted technical strategies $(\overline{\mathrm{x}}=3.89)$ on average more because it had the highest mean score, followed by the adoption of preventive strategies $(\overline{\mathrm{x}}=3.66)$. However, participants disagreed that they adopted reactive strategies $(\overline{\mathrm{x}}=3.36)$ as a coping strategy against cyberbullying. This suggests that participants adopted technical strategies and prevented cyberbullying more than using reactive means of coping with cyberbullying.

\section{Hypothesis Testing}

Hypothesis: Students' demography does not significantly influence their adoption of coping strategies against cyberbullying communication

Table 3: ANOVA \& Model Summary Testing Significant Influence of

Demography on Adoption of Coping Strategies

\begin{tabular}{|l|l|l|l|l|l|l|}
\hline \multicolumn{2}{|l|}{ Model } & $\begin{array}{l}\text { Sum of } \\
\text { squares }\end{array}$ & df & $\begin{array}{l}\text { Mean } \\
\text { square }\end{array}$ & F & Sig. \\
\hline \multirow{3}{*}{1} & Regression & 9623.141 & 6 & 1603.857 & 45.232 & $0.000^{b}$ \\
\cline { 2 - 7 } & Residual & 28686.069 & 809 & 35.459 & & \\
\cline { 2 - 7 } & Total & 38309.210 & 815 & & & \\
\hline
\end{tabular}

$\mathrm{R}=0.501$

$\mathrm{R}$ Square $=0.2$. Adjusted R Square $=0.246$

Table 3 shows the ANOVA and model summary computations with the test of the significant influence of demography on the adoption of coping strategies.

Table 4: Multiple Linear Regression Testing Significant Influence of Demography on Adoption of Coping Strategies

\begin{tabular}{|l|l|l|l|l|}
\hline Construct & $\mathrm{B}$ & $\mathrm{r}$ & $\mathrm{T}$ & Sig. \\
\hline (Constant) & 74.376 & & 43.827 & $\mathbf{0 . 0 0 0}$ \\
\hline Institution & -0.260 & -0.048 & -1.545 & 0.123 \\
\hline Gender & -0.130 & 0.009 & -0.258 & 0.797 \\
\hline Marital status & -8.851 & -0.522 & $-14 . .841$ & 0.000 \\
\hline Age & -.865 & -0.058 & -1.768 & 0.077 \\
\hline Year of study & -2.272 & -0.321 & -8.607 & $\mathbf{0 . 0 0 0}$ \\
\hline Religion & 0.218 & 0.016 & 0.486 & .0 .627 \\
\hline Criterion variable: & Adoption of coping strategies \\
\hline
\end{tabular}


Tables 3 and 4 indicate that demography significantly influenced the adoption of coping strategies against cyberbullying ( $\mathrm{F}$ $(1,814)=45.232, \mathrm{p}<0.05)$. From a relative perspective, participants' marital status $(r=-0.522, p<0.05)$ had a moderate negative significant influence on the adoption of coping strategies. Year of study $(\mathrm{r}=-$ $0.321, \mathrm{p}<0.05)$ also had a negative, weak significant influence on the adoption of coping strategies. This suggests that participants who are single likely increase the adoption of cyberbullying coping strategies. Also, the analysis suggests that as participants' level of studentship reduces, there is likely to be increased adoption of cyberbullying coping strategies. Conversely, other demographic variables examined had no significant influence on participants' adoption of coping strategies.

The model indicates that demography explained 25.1 percent (Adj. $\left.\mathrm{R}^{2}=0.246\right)$ variation of adoption of coping strategies; hence, there were other factors not considered in this study. Therefore, the null hypothesis that students' demography does not significantly influence their adoption of coping strategies against cyberbullying communication was rejected.

\section{Discussion of findings}

Strategies adopted by students in coping with cyberbullying
As earlier stated, the present study found that generally, participants agreed that they adopted cyberbullying coping strategies $(\overline{\mathrm{x}}=3.64)$. Respondents adopted technical strategies $(\overline{\mathrm{x}}=3.89)$ on average more because it had the highest mean score, followed by the adoption of preventive strategies $(\overline{\mathrm{x}}=3.66)$. However, participants disagreed they adopted reactive strategies $(\overline{\mathrm{x}}=3.36)$ as coping strategies against cyberbullying. This suggests that participants adopt technical and preventive strategies more in coping with cyberbullying and reactive strategies to a lesser degree. The technical and preventive strategies include blocking the bully, tracking him through internet protocol address, blacklisting his number, staying away from unsafe websites, protecting passwords, bullying the bully back, ignoring the bullying by taking his action as something ordinary or unimportant, deleting bully's messages, and closing one's accounts.

The finding is similar to that of Parris, Varjas, Meyers and Cutts (2011), who carried out a study on how high school students perceived coping with cyberbullying. The respondents reported that among other strategies, they adopted preventive and reactive coping strategies. The reactive coping strategies included avoiding acts of cyberbullying, deleting messages, 
deleting online accounts, blocking bully's numbers, ignoring the situation as unimportant, accepting cyberbullying as a normal part of life that could not be stopped, and, letting it go. It is also justifying the cyberbullies' actions by focusing on his negative characteristics like his cowardice and lack of maturity; as such, he should not be a cause of worry; and reporting him to a person in authority to stop him. As for preventive coping strategies, they included talking in person with the bully if possible and increasing security measures online. Prescriptions by respondents under this strategy included talking or confronting the bully personally, increasing security measures like password protection, limiting identifying information otherwise known as self-disclosure, as well as overall awareness, such as knowing websites that might not be safe and staying away from them. These definitions form part of the ones used in this study.

An agreement also exists between the finding and that of Smith, Mahdavi, Carvalho, Fisher, Russell and Tippett (2008) in their studies in the UK, where the respondents recommended blocking/avoiding messages of bullies and telling someone about the incident, as the best coping strategies. Similarly, it aligns with that of Monks, Robinson and
Worlidge (2012) in another study, where recommended coping strategies by respondents were blocking the cyberbullying messages and changing e-mail addresses or phone numbers. However, very few of these respondents (under 7\%) prescribed fighting the bully back. A further breakdown of the suggested responses included, blocking messages $(64.8 \%)$, changing e-mail addresses or phone number $(57.0 \%)$, telling someone else (75.2\%), ignoring it $(47.9 \%)$, asking the perpetrators to stop $(38.2 \%)$ and fighting back (6.7\%). The participants were also sampled on whether they thought victims felt specific emotion while responding to cyberbullying. The researchers found that participants were most likely to state that they would feel stressed (48.2\%), afraid/scared $(57.6 \%)$, worried (58.4\%), angry (39.8\%), upset (56.6\%), embarrassed (26.5\%), depressed (39.8\%) and not affected (15.7\%).

Another study's findings in agreement with this study on different coping strategies are those of Slonje, Smith and Frisén (2013). The respondents in the study prescribed practical strategies such as changing numbers, blocking the bully, not giving out one's number, tracking IP addresses, or permanently blocking abusers by 
contacting administrators of affected websites.

Also in alignment are the works of other researchers (Aricak, Siyahhan, Uzunhasanoglu, Saribeyoglu, Ciplak, Yilmaz, \& Memmedov, 2008; Smith, Mahdavi, Carvalho, Fisher, Russell, \& Tippett, 2008; Smith et al., 2008; Aricak et al., 2008) who examined children and adolescents on their coping strategies. The solutions prescribed by respondents consisted of blocking certain people from making contact with one online, changing one's passwords, user names or e-mail addresses, and deleting anonymous text messages without reading them.

Other coping strategies have been mentioned often by cyber victims in similar studies. Such strategies include switching one's name on online accounts or changing phone numbers (Juvoven \& Gross, 2008; Aricak et al., 2008; Smith et al., 2008). Some of the respondents chose more aggressive ways of online coping such as responding online, telling the bully point-blank to stop harassing them (Aricak et al., 2008), or even bullying the bully back (Dehue, Bollman, \& Völlink, 2008). There were expected cases of pessimism among some of the respondents with one, a 14-year-old girl, saying cyberbullying was "unstoppable."

\section{Students' demography and adoption of coping strategies against cyberbullying}

As mentioned earlier, this finding shows that demography significantly influenced the adoption of coping strategies against cyberbullying ( $\left.\mathrm{F}_{(1,} \quad 814\right)$ $=45.232, \mathrm{p}<0.05)$. From a relative perspective, respondents' marital status $(r=-0.522, p<0.05)$ had a moderate negative significant influence on the adoption of coping strategies. Year of study $(\mathrm{r}=$ $0.321, \mathrm{p}<0.05$ ) also had a negative, weak significant influence on the adoption of coping strategies. This suggests that respondents who are single likely increase the adoption of cyberbullying coping strategies. Also, the analysis suggests that as respondents' level of studentship reduces, there is likely to be increased adoption of cyberbullying coping strategies.

Conversely, other demographic variables examined had no significant influence on participants' adoption of coping strategies. The model indicates that demography explained 25.1 percent $\left(\mathrm{R}^{2}=0.251\right)$ variation of adoption of coping strategies; hence, there were other factors not considered in this study. Therefore, the null hypothesis, which states that students' demography does not significantly influence their 
adoption of coping strategies against cyberbullying, was rejected.

This finding is in agreement with that of Agatston, Kowalski, and Limber (2007), which confirms that demography influences coping strategies adopted by the youth. The researchers discovered that coping strategies adopted by respondents varied with their age and sex. In the American study, the researchers examined responses from focus groups in two middle schools and two high schools made up of 148 students, with an age range between 12 and 17 years. In carrying out the focus group discussions, the scholars divided the respondents by gender. Results from the study showed that the students were familiar with technology and its use, with most of them having their mobile phones and access to the internet in their homes. Some respondents also signified that they did not think the adults at school could help them cope if they experienced cyber victimization. Instead, they were very likely to report to parents rather than adults at school, as a preferred coping strategy, especially if the bullying was threatening in nature.

Nevertheless, some affirmed that they were not very eager to tell parents because of the fear that parents might put an end to their online privileges. The question of who among the male or female students will tell adults when cyberbullying occurs (another type of coping strategy) was examined concerning gender differences $(\mathrm{Li}$, 2006). Furthermore, the result showed that for cyber victims, females were more likely to inform adults than males.

The implication of this is that the demographic characteristic of the students matters a lot when they adopt coping strategies. What a female undergraduate will do to cope with cyberbullying is likely to be different from what a male will do.

\section{Conclusion}

Demography is an essential variable in students' adoption of coping strategies against cyberbullying as data showed it significantly influenced the adoption of the strategies. From the preliminary analysis of data obtained from the field, the two demographic characteristics that could be considered as having a significant influence on the adoption of coping strategies are marital status and year of study of the participants. Other demographic variables examined had no significant influence on participants' adoption of coping strategies. As earlier observed from a relative perspective, participants' marital status $(\mathrm{r}=-0.522, \mathrm{p}<0.05)$ 
had a moderate negative significant influence on the adoption of coping strategies. The keywords here are 'moderate' and 'negative.' This indicates that students who are married seem not interested in adopting coping strategies against cyberbullying because, in the first place, it seems they are not heavy users of the internet. This may be because they have family, marital, and community engagements that share available time, including internet time, with them as such they are more likely to devote less time to the internet. When one does not visit the internet, the possibility of encountering online bullies or adopting coping strategies against attacks is lower. The suggestion that single participants likely increased the adoption of cyberbullying coping strategies is, therefore, appropriate as the unmarried students will likely have more time to spend on the internet as they may not have external commitments like their married colleagues.

Year of study $(\mathrm{r}=-0.321$, $\mathrm{p}<0.05)$ also had a negative, weak significant influence on the adoption of coping strategies. The keywords are 'negative' and 'weak.' The scenario suggests that as participants' level of studentship reduces, there is likely to be increased adoption of cyberbullying coping strategies. This means students who are in their earlier years of study, for example, from 100 and 200 levels, adopt more coping strategies as they surf the internet more. This could be a carryover from their high school or secondary school days when most were addicted to their smartphones. They also seem to have more time to browse the internet and social media as they are more involved in campus social life and merrymaking activities. However, as they get to their advanced levels of study, like 400 or 500 level students tend to devote more time to search for educational materials, which will add value to their studies and contribute to their final year research projects. They may not have time for social browsing or unproductive chats again at these levels. Furthermore, their constant visits to online educational sites mean less exposure to cyberbullies and less adoption of coping strategies. Cyberbullies are found mostly on social media sites like Facebook, Instagram, WhatsApp, and Twitter, and these sites have little or no interest in scholarly and educational content.

\section{Recommendations}

- undergraduates should adopt appropriate coping strategies in fighting cyberbullying communication, 
- ICT units of universities should design filters that would monitor the usage of campus internet bandwidth to prevent cyberbullying communication,

- anti-cyberbullying messages and preventive campaigns from university authorities should target more single students and students who are relatively new on campus as they are likely to be more involved in online

\section{References}

Agatston, P. W., Kowalski, R. \& Limber, S. (2007). Students' perspectives on cyberbullying. Journal of Adolescent Health, 41, S59S60.

Amodu, L., Omojola, O., Okorie, N., Adeyeye, B \& Adesina, E. (2019). Potentials of Internet of Things for effective public relations activities: Are professionals ready? Cogent Business \& Management, 6:1, DOI: 10.1 080/23311975.2019.1683951

Anti-Bullying Alliance (2009). New Research on Cyberbullying Highlights the Role of Parents in Prevention. Retrieved from http://www.antibullyingalliance.org.uk/press _centre/ news_archive/ New- bullying activities and adoption of possible coping strategies,

- cyberbullying is harmful communication; as such, students should avoid suspicious, harmful, and immoral sites but devote more time in search of educational materials, which will add value to their studies.

research-on-

cyberbullying.aspx.

Aricak, T., Siyahhan, S., Uzunhasanoglu, A., Saribeyoglu, S., Ciplak, S., Yilmaz, N., \& Memmedov, C. (2008). Cyberbullying among Turkish adolescents. Cyberpsychology and Behavior, 11(3), 253-261. DOI:10.1089/cpb.2007.0016. Bjorkqvist, K., Lagerspetz, K. M., \& Kaukiainen, A. (1992). Do girls manipulate and boys fight? Developmental trends in regard to direct and indirect aggression. Aggress Behavior, 18:11727. DOI:10.1002/10982337(1992)18:2-117:AID AB2480180205>3.0.CO;2-3.

Borg, M. G. (1999). The extent and nature of bullying among primary and secondary school children', 
Educational Research 41(2), 137-53.

Boulton, M. \& Underwood, K. (1992). Bully/victim problems among middle school children', British Journal of Educational Psychology 62, 73-87.

Byron Review (2008). Safer children in a digital world: The report of the Byron Review. Retrieved from http://www.dcsf.gov.uk/byro nreview/pdfs/Final\%20

Report\%20

Book

marked.pdf.

Carphone Warehouse (2006). Mobile life youth report: The impact of the mobile phone on the lives of young people. Retrieved from http://www.mobilelife2008.c o.uk/mobilelife2007/.

http://net.educause.edu/ir/libr ary/pdf/ERS0808/RS/ERS08 08w.pdf.

Cassidy, W., Jackson, M., \& Brown, K. (2009). Sticks and stones can break my bones, but how can pixels hurt me? Students' experiences with cyber-bullying. School Psychology International, 30, 383-402,

DOI: $10.1177 / 014303430910$ 6948.

Check, J., \& Schutt, R. K. (2012). Survey research. In Check, J. \& Schutt. R. K.
(Eds). Research methods in education, 159 185. Thousand Oaks, CA: Sage Publications.

Comrey, A. \& Lee, H. (1992). A

first course in factor analysis. Hillside, $\mathrm{NJ}$ :

Lawrence Erlbaum.

Crick, N. R., \& Grotpeter, J. K. (1996). Children's treatment by peers: Victims of relational and overt aggression. Development and Psychopathology,8(2),367380.

DOI:10.1017/S09545794000 07148.

Crick, N. R., Werner, N. E., Casas, J. F., O'Brien, K. M., Nelson, D. A., Grotpeter, J. K., \& Markon, K. (1999). Childhood aggression and gender: A new look at an old problem. In Bernstein, D. (Ed.), The Nebraska symposium on motivation: Vol. 45. Gender and Motivation, p. 75-141. Omaha, NE: University of Nebraska Press.

Dehue, F., Bollman, C., \& Völlink, T. (2008). Cyberbullying: Youngsters' experience and parental perception. Cyberpsychology \& Behavior, 11, 217-223.

Eslea, M. \& Mukhtar, K. (2000). Bullying and racism among Asian school children in 
Britain. Educational

Research, 42(2), 207-17.

Folayan, B.J., Omojola, O.,

Egharevba, M., Oyesomi, K.,

Yartey, D \& Adeyeye, B. (2018). The use of ICTrooted communication codes and slangs among Nigerian students. The Journal of Social Sciences Research, 4(12), 633-641.

Hinduja, S., \& Patchin, J. W. (2009). Bullying beyond the schoolyard. Thousand Oaks, CA: Corwin.

Hinduja, S., \& Patchin, J. W. (2010a). Bullying, cyberbullying, and suicide. Archives of Suicide Research, 14(3), 206-221. DOI:

10.1080/13811118.201.4941 33.

Hoover, J. \& Olsen, G. (2001). Teasing and harassment: The frames and scripts approach for teachers and parents. Bloomington: National Educational Service.

Jones, S. (2002). The internet goes to college. Pew Internet and American life project.

Retrieved from http:/www.pewInternet.org/ Juvoven, J., \& Gross, E. F. (2008). Bullying experiences in cyberspace. Journal of School Health, 78, 496-505.
Kelman, H. C. (1958). "Compliance, Identification, and Internalization: Three Processes of Attitude Change," Journal of Conflict Resolution (2:1), 51-60.

Kumar, R. \& Kaur, A. (2006). Internet use by teachers and students in engineering colleges of Punjab, Haryana, and Himachal Pradesh states of India: An analysis. Electronic. J. Academic Special Librarianship, 7(1): 1-12.

Kumpulainen, K., Rasanen, E., Henttonen, I., \& Almqvist, F. (1998). Bullying and psychiatric symptoms among elementary school-age children. Child Abuse and Neglect: The International Journal, 22(7): 705-17.

Kumpulainen, K., Rasanen, E., \& Henttonen, I. (1999). Children involved in bullying: psychological disturbance and the persistence of the involvement', Child Abuse and Neglect: The International Journal, 23(12): 1253-62.

Livingstone, S., Haddon, L., Görzig, A., \& Ólafsson, K. (2011). Risks and safety on the Internet: The perspective of European children. Full 
findings. LSE, London: EU Kids Online.

Li, Q. (2006). Cyberbullying in schools: A research of gender differences. School Psychology International, 27, 157 - 170. doi: $10.1177 / 0143034306064547$.

Li, Q. (2007). New bottle but old wine: A research of cyberbullying in schools. Computers in Human Behavior, 23(4), 1777-1791. DOI:

10.1016/j.chb.2005.10.005.

Mitchell, K., Finkelhor, D., \& Becker-Blease, K. (2007). Linking youth Internet and conventional problems: Findings from a clinical perspective. Crimes Against Children Research, 15(2), 39-58.

Monks, C. P., Ortega, R., Robinson, S., \& Worlidge, P. (2009). Cyberbullying among primary school-aged pupils. Kwartalnik Pedagogiczny, 4, 167-181.

Monks, C. P., Robinson, S., \& Worlidge, P. (2012). The emergence of cyberbullying: A survey of primary school pupils' perceptions and experiences. School Psychology International, 33(5), 477-491. DOI: $10.1177 / 0143034312445242$.
Morah, N. \& Omojola, O. (2014) Digital large screens as a community medium: interactivity and community relevance in focus. In $\mathrm{A}$. Ojebode (Ed.) Community Media in Nigeria. Ibadan: John Archer Publishers, pp. 385-402.

Ojebode, A., Onekutu, P. \& Adegbola, T. (2010). Audience research methods for campus radio stations. Lagos: Institute for Media and Society.

Okorie, N., Loto, G. \& Omojola, O. (2018). Blogging, civic engagement, and coverage of political conflict in Nigeria: A study of Nairaland. com. Kasetsart Journal of Social Sciences 39 (2), 291-298.

Olweus, D. (1991). Bully/victim problems among schoolchildren: Basic effects of a school based intervention program. In Pepler, D., \& Rubin, K. (eds), The Development and Treatment of Childhood Aggression, p. 411-48. Hillsdale, NJ: Erlbaum.

Omojola, O. (2008). Web Searching in a Nigerian Language: An Assessment of Google Yoruba. Ibadan Journal of the Social Sciences, 6 (2), 167-177. 
Omojola, O. (2009). Englishoriented ICTs and ethnic language survival strategies in Africa. Global Media Journal (African Edition), 3 (1). Retrieved May 12, 2020 , from

https://globalmedia.journals. ac.za/pub/article/view/18.

Omojola, O. (2010) Exploring the impact of Google Igbo in southeast Nigeria. In $R$. Lekoko \& L. Semali (eds) Cases on developing countries and ICT integration: Rural community development. Hershey, Pennsylvania: IGI Global Publishing,

Omojola, O. (2014). Women's Political Visibility and Media Access: The Case of Nigeria.

Newcastle:

Cambridge Scholarship Publishing.

Parris, L., Varjas, K., Meyers, J., \& Cutts, H. (2011). High school students' perceptions of coping with cyberbullying. Youth \& Society, $X X(\mathrm{X})$ 1-23. DOI: 10.1177/0044118X 11398881.

Pellegrini, A., \& Bartini, M. (2000). A longitudinal study of bullying, victimization, and peer affiliation during the transition from primary school to middle school,
American

Educational

Research Journal, 37(3), 699-725.

Ponto, J. (2015). Understanding and evaluating survey research. Journal of the Advanced Practitioner in Oncology, 6(2), 168-171. Retrieved from https://www.ncbi.nlm.nih.go v/pmc/articles/PMC4601897/ Rigby, K., \& Slee, P. T. (1999). Suicidal ideation among adolescent school children, involvement in bully-victim problems, and perceived social support. Suicide and Life Threatening Behavior, 29(2), 119-130.

Saunders, M., Thornhill, A., \& Lewis, P. (2009). Research Methods for Business Students, New Jersey: Prentice. Hall.

Seals, D., \& Young, J. (2003). Bullying and victimization: prevalence and relationship to gender, grade level, ethnicity, self-esteem, and depression.

Adolescence.38(152), 735 47.

Shakeshaft, C., Barber, E., Hergenrother, M., Johnson, Y., Mandel, L., \& Sawyer, J. (1995). Peer harassment in schools. Journal for a Just Education, 1(1), 30-40 
Slonje, R., \& Smith, P. K. (2008). Cyberbullying: Another main type of bullying?

Scandinavian Journal of Psychology, 49, 147-154. DOI: $\quad 10.1111 / \mathrm{j} .1467 \quad-$ 9450.2007.00611.x.

Slonje, R., Smith, P.K. \& Frisén, A. (2013). The nature of cyberbullying and strategies for prevention. Computers in Human Behavior. 29(1) 26 -32 .

Smith, P. K., Mahdavi, J., Carvalho, M., Fisher, S, Russel, S., \& Tippett, N. (2008). Cyberbullying: Its nature and impact in secondary school pupils. Journal of Child Psychology and Psychiatry, 49(4), 376385. DOI:10.1111/j.14697610.2007. 01846.x

Sourander, A., Klomek, A. B., Ikonen, M., Lindroos, J., Luntamo, T., Koskelainen, M., Ristkari, T. \& Helenius, H. (2010). Psychosocial risk factors associated with cyberbullying among adolescents. A populationbased study. Arch Gen Psychiatry, 67(7), 720-728. doi:10.1001/archgenpsychiat ry.2010.79.
Subrahmanyam, K., \& Greenfield, P. (2008). Online communication and adolescent relationships. Future Child, 18(1), 119146.

DOI: $10.1353 /$ foc. 0.0006

Tannen, D. (1994). Talking from 9 to 5. New York: Quill, Harper Collins Publishers. Teenager killed himself after being 'bullied on Snapchat' Retrieved from

Wimmer, R. D., \& Dominick, J. R. (2011). Mass media research: An introduction ( $9^{\text {th }}$ ed.). Canada: Wadsworth, Centage Learning.

Wiseman, R. (2002). Queen Bees and Wannabees. New York: Three Rivers Press.

Wolke, D., Woods, S., \& Bloomfield, L. (2000). The association between direct and relational bullying and behavior problems among primary school children. Journal of Child Psychology and Psychiatry.41, $\quad 989$ 1002. DOI:10.1111/14697610.00687. 